УдК 792.82:7.071.2(100+477)

DOI: 10.31866/2616-7646.2.1.2019.172181

\title{
ТВОРЧА ДІЯЛЬНІСТЬ ВАЦЛАВА ТА БРОНІСЛАВИ НІЖИНСЬКИХ У КОНТЕКСТІ РОЗВИТКУ СВІТОВОГО Й УКРАЇНСЬКОГО БАЛЕТНОГО МИСТЕЦТВА
}

\author{
Хоцяновська Людмила Францівна, \\ доцент, заслужена артистка України, \\ Київський національний університет культури і мистецтв, \\ Київ, Україна, \\ https://orcid.org/0000-0001-8451-3185, \\ khotsyaQukr.net \\ Білаш Ольга Сергіївна, \\ доцент, заслужений працівник культури України, \\ Київський національний університет культури і мистецтв, \\ Київ, Україна, \\ https://orcid.org/0000-0002-6910-2238, \\ bilash.olga96agmail.com
}

Мета дослідження - проаналізувати ключові аспекти творчої діяльності відомих хореографів українського походження Вацлава та Броніслави Ніжинських і розкрити їхню роль у розвитку світового та вітчизняного балетного мистецтва. Методологія. У дослідженні застосовано історико-хронологічний та біографічний методи для з'ясування фактів творчої біографії митців; системний метод дав змогу комплексно й об'єктивно дослідити основні тенденції творчості хореографів у контексті тодішнього розвитку балетного мистецтва. Наукова новизна дослідження полягає в цілісній систематизації основних біографічних відомостей та особливостей творчого шляху Вацлава й Броніслави Ніжинських, а також у висвітленні взаємозв'язку їхньої творчості зі світовим та вітчизняним балетним мистецтвом. Висновки. Творча діяльність родинного тандему Вацлава й Броніслави Ніжинських належить до визначних явищ у хореографічному мистецтві України початку XX ст.; вона суттєво вплинула на європейські та загальносвітові тенденції розвитку балетного мистецтва. Б. Ніжинська, творчий пошук якої здійснювався в середовищі новітніх авангардних ідей культури й мистецтва, $є$ автором педагогічних методів та принципів нової балетної школи руху, що склали важливе підгрунтя для формування професійної діяльності в тогочасному хореографічному мистецтві. Винятковий артистизм, пластичність і майстерність відзначають професійну діяльність В. Ніжинського. У творчому доробку брата й сестри чимала кількість балетних постановок, які сприяли формуванню новаторського погляду на балетне мистецтво, роль у виставі танцівника й багатогранне розкриття образу.

Ключові слова: Вацлав Ніжинський; Броніслава Ніжинська; «Школа руху»; балетні вистави; хореографічне мистецтво. 


\section{ТВОРЧЕСКАЯ ДЕЯТЕЛЬНОСТЬ ВАЦЛАВА И БРОНИСЛАВЫ НИЖИНСКИХ В КОНТЕКСТЕ РАЗВИТИЯ МИРОВОГО И УКРАИНСКОГО БАЛЕТНОГО ИСКУССТВА}

\author{
Хоцяновская Людмила Францевна, \\ доцент, заслуженная артистка Украины, \\ Киевский национальный университет \\ культуры и искусств, \\ Киев, Украина, \\ https://orcid.org/0000-0001-8451-3185, \\ khotsya@ukr.net \\ Билаш Ольга Сергеевна, \\ доцент, заслуженный работник культуры \\ Украины, \\ Киевский национальный университет \\ культуры и искусств, \\ Киев, Украина, \\ https://orcid.org/0000-0002-6910-2238, \\ bilash.olga96agmail.com
}

Цель исследования - проанализировать ключевые аспекты творческой деятельности известных хореографов украинского происхождения Вацлава и Брониславы Нижинских и раскрыть их роль в развитии мирового и отечественного балетного искусства. Методология. В исследовании применены историко-хронологический и биографический методы для выяснения фактов творческой биографии творцов; системный метод позволил комплексно и объективно исследовать основные тенденции творчества хореографов в контексте тогдашнего развития балетного искусства. Научная новизна исследования заключается в целостной систематизации основных биографических сведений и особенностей творческого пути Вацлава и Брониславы Нижинских, а также в освещении взаимосвязи их творчества с мировым и отечественным балетным искусством. Выводы. Творческая деятельность семейного тандема Вацлава и Брониславы Нижинских принадлежит $\mathrm{k}$ выдающимся явлениям в хореографическом искусства Украины

\section{VACLAV AND BRONISLAVA NIZHINSKY'S \\ CREATIVE ACTIVITY IN THE CONTEXT OF THE WORLD AND UKRAINIAN BALLET ART DEVELOPMENT}

\author{
Liudmyla Khotsianovska, \\ assistant professor, \\ Honored Artist of Ukraine, \\ Kyiv National University of Culture and Arts, \\ Kyiv, Ukraine, \\ https://orcid.org/0000-0001-8451-3185, \\ khotsya@ukr.net \\ Olha Bilash, \\ assistant professor, Honored Worker \\ of Culture of Ukraine, \\ Kyiv National University \\ of Culture and Arts, \\ Kyiv, Ukraine, \\ https://orcid.org/0000-0002-6910-2238, \\ bilash.olga96agmail.com
}

The purpose of the article is to analyze and systematize the creative activity of famous choreographers of Ukrainian origin, Vaclav and Bronislava Nizhinsky, and their role in the world and domestic ballet art development. Methodology. The historical-chronological and biographical methods have been used in this article to find out the artists' creative biography facts; the systematic method made it possible to comprehensively and objectively examine the main tendencies of creativity in the context of contemporary development in the ballet art. Scientific novelty consists in the complete systematization of biographical information and Vaclav and Bronislava Nijinsky creative path, the interrelationships definition of their work. Conclusions. The family tandem Vatslav and Bronislava Nizhinsky belong to the outstanding phenomena in the choreographic art development in Ukraine at the beginning of the 20th century and they are marked by the influence on $\mathrm{Eu}$ ropean and world tendencies in the development of ballet art. B. Nizhinskaya, whose creative search was carried out among the newest 
начала XX в.; она оказала существенное влияние на европейские и общемировые тенденции развития балетного искусства. Б. Нижинская, творческий поиск которой осуществлялся в среде новейших авангардных идей культуры и искусства, является автором педагогических методов и принципов новой балетной школы движения, что составило важное основание для формирования профессиональной деятельности в тогдашнем хореографическом искусстве. Исключительный артистизм, пластичность и мастерство отмечают профессиональную деятельность В. Нижинского. В творчестве брата и сестры немалое количество балетных постановок, которые содействовали подъему новаторского взгляда на балетное искусство, роль в спектакле танцовщика и многогранное раскрытие образа.

Ключевые слова: Вацлав Нижинский; Бронислава Нижинская; "Школа движения»; балетные спектакли; хореографическое искусство. avant-garde culture and art, there is the author of pedagogical methods and principles in the new ballet school of movement, which formed an important basis for the professional activity formation in contemporary choreographic art. Exclusive artistry, plasticity and craftsmanship mark the professional creative activity of V. Nizhinsky. In the creative work of the brother and sister there are a large number of created new ballet productions, which served the rise of the latest look at ballet art, the discovery of the role of the dancer in the spectacle, the disclosure of the image.

Keywords: Vaclav Nizhinsky; Bronislava Nizhinskaya; School of Movement; ballet performances; choreographic art.

Актуальність теми дослідження. Формування світового й українського балетного мистецтва на початку XX ст. мало певні особливості, що вплинули на його характер і профіль, а загалом - на подальший розвиток. Започаткування балетних шкіл на теренах України збігається з часом переосмислення й трансформування мистецької хореографічної спадщини, обумовлюючи видозміну класичного балету (Коваленко, 2012, с. 124). Вагому роль у цьому процесі відіграє родинна творча діяльність визначних танцівників і балетмейстерів XX ст. Вацлава та Броніслави Ніжинських. Їхній батько - Хома (Томаш) Ніжинський - був знаним хореографом, який прищепив своїм дітям любов до танцю, а мати Елеонора допомогла їм розвинути талант. Характеризуючи творчість на ниві хореографічного мистецтва батька - Х. Ніжинського, дослідники відзначають, що він вдало поєднував традиції української, польської та російської культур. Зокрема, це знайшло яскраве вираження в постановці опери «Катерина» М. Аркаса, де було поєднано дванадцять пар артистів балету з виконавцями провідних вокальних партій (Шабаліна, 2016, с. 267).

Прагнення до оновлення класичного танцю на основі мистецьких новацій, що знаходило реалізацію в балетних постановках В. та Б. Ніжинських, було дзеркальним відображенням їньої сценічної віртуозності як балетних артистів, котрі сміливо реалізовували виконавські можливості танцівника в нових формах балетного театру, досягаючи в такий спосіб багатогранного образного розкриття ролей. Творча спадщина митців $\epsilon$ актуальною для осмислення шляхів розвитку 
балетного мистецтва в Україні та світі; позначена транскультурними зв’язками, вона вимагає належного наукового вивчення.

Аналіз останніх досліджень і публікацій. Творча діяльність родини Ніжинських ще не була предметом наукового дослідження, а увага до аналізу педагогічної діяльності й балетної творчості Вацлава та Броніслави Ніжинських носила спорадичний характер і зазвичай присвячувалася комусь одному. Хоча для осмислення мистецького феномену родини Ніжинських у розвитку вітчизняного та світового балетного мистецтва доцільно вивчати їхню творчість у тісному взаємозв’язку крізь призму ідей і пошуків у культурі й мистецтві, притаманних першій чверті XX ст. Творчій діяльності Б. Ніжинської присвячені роботи Ю. Волхонович (Волхонович, 1997) М. Ратанової (Ратанова, 1999); М. Курінної (Курінна, ), в яких висвітлюється життєвий і творчий шлях балерини й балетмейстера, діяльність заснованої нею «Школи руху» та аналізується методична спадщина 3 хореографічного мистецтва. Творча діяльність Вацлава Ніжинського знайшла відображення у працях останніх років Т. Кузовльової (2013), О. Петренко (2013), О. Полісадової (2016), О. Портнової (2016), О. Сидора (2014). ропоноване дослідження є спробою цілісного погляду на творчу діяльність визначних хореографів, що розвивалася в річищі загальних тенденцій культурно-мистецького життя початку XX ст.

Мета статті - проаналізувати ключові аспекти творчої діяльності відомих хореографів українського походження Вацлава та Броніслави Ніжинських і з'ясувати їхню роль у розвитку світового та вітчизняного балетного мистецтва.

Виклад основного матеріалу. XX ст. привнесло в балет, хореографію (i ширше, танцювальне мистецтво) нову енергетику i, як наслідок, - нові форми руху. Активізувалися процеси міжвидового синтезу мистецтв, а також процес інтеграції художньої та позахудожньої сфер, що покликало до життя чимало надзвичайно цікавих явищ на балетній сцені (Зінич, 2009, с. 80).

В. Ніжинський народився в Києві у 1889 р., із п’ятирічного віку брав участь у сценічних виступах. Після розлучення батьків він з матір’ю, братом і сестрою переїхав до Петербурга. Саме там у віці 9 років Вацлав став учнем балетної школи в класі М. Легата. Наприкінці другого курсу був обраний для участі в балетних виставах Маріїнського театру, де дебютував у мазурці з балету «Пахіта». Після отримання диплома В. Ніжинський офіційно став артистом трупи. Його виступи супроводжували позитивні рецензії, а у відгуках ім'я В. Ніжинського стояло поряд з іменами таких знаних балерин, як Тамара Карсавіна і Матильда Кшесинська.

Слід зазначити, що у творчій долі В. Ніжинського знакову роль відіграв відомий театральний та художній діяч, антрепренер Сергій Дягілєв, який став всесвітньо відомим завдяки «Російським сезонам» у Парижі і трупі «Російський балет Дягілєва». С. Дягілєв був першим, хто взяв на себе роль своєрідного «відкривача талантів»; він активно досліджував нові засоби вираження в живописі, музиці, театрі, звертався до нових тем, які раніше не розглядалися в романтичному балеті. Саме С. Дягілєв прозорливо вловив і передбачив назрілу потребу в реформі балету, великі потенційні можливості поєднання техніки класичного танцю із пластикою «вільного» танцю (Зінич, 2009, с. 81).

Участь В. Ніжинського в антрепризі С. Дягілєва мала величезний успіх у публіки. У цей період Вацлав виконував головні чоловічі партії в більшості балетів програми виступів «Російських сезонів». 
13 травня 1912 р. почався четвертий сезон у Парижі в театрі Шатле. Тут уперше було представлено спектакль Ніжинського як хореографа, який називався «Післяполудневий відпочинок Фавна», де з'явилися нові форми руху і новий стиль балетного костюму. Дослідники відзначають, що Ніжинський став найяскравішою зіркою «Російських сезонів» С. Дягілєва, створивши новий тип танцівника на сцені. I це змінило всю виконавську парадигму чоловічого танцю в XX ст. Найкардинальнішим відкриттям В. Ніжинського стане виявлення невідомих на той час ресурсів хореографічної лексики, котрі розширювали межі сформованих канонів балетного театру (Полисадова, 2016, с. 75).

У творчості Ніжинського - танцівника й балетмейстера - відбилися всі новаторські пошуки, які явно проникали з інших видів мистецтва на балетну сцену: створення нового костюма, зміна сценографічного простору, аналіз музики як драматичного твору і створення нової танцювальної мови. Чоловічий танець на балетній сцені став самодостатнім, віртуозним і драматургічно насиченим. Hiжинський був наділений видатним природним акторським талантом, його техніка танцю, а особливо стрибка, була такою, що в глядачів виникалося враження повної безтілесності виконавця від стрімкості розбігу й майже нереальної висоти самого стрибка. Ніжинський зумів вивести в мистецтві балету на перший план танцівника як носія головних смислів вистави, що було кардинальною відмінністю від балету XIX ст.

1913 р. став останнім роком В. Ніжинського в європейському світі з антрепризою Дягілєва. Того ж року у Відні розпочалися репетиції нового балету Ніжинського, який називався «Весна священна». Під час репетицій виникли розбіжності між хореографом і танцівниками.

Прем’єра балету «Весна священна» І. Стравінського в постановці В. Ніжинського відбулася в Парижі в Театрі Єлисейських полів 29 травня 1913 р. Саме в цей день балет був «освистаний» публікою. Композитор змушений був покинути глядацьку залу після перших же тактів вступу, які викликали крики обурення вихованої на творах класицизму паризької публіки.

I все ж ця постановка була незвично вражаючою. Балет В. Ніжинського кидав виклик рафінованому естетизму, на якому був вихований глядач «Російських сезонів» С. Дягілєва. Жертвопринесення особистості і варварство суспільства - тема пророчо актуальна напередодні Першої світової війни. Балет став маніфестом сучасного мистецтва, прокладаючи дорогу в бік футуризму й експресіонізму.

Унікальність бачення В. Ніжинського полягала ще й у тому, що він, ідучи за музикою та ідеями танцю модерн, передбачаючи балет майбутнього, композиційно вибудовував хореографію на асиметрії та алогізмі. Мальовничо розкидані групи кордебалету, безладні рухи танцівників, які вводили персонажів до стану трансу, сцени обряду, що були на межі мистецтва й реальності, перепліталися з абстрактним хореографічним малюнком. Дія організовувалася лише ритмом, а він у балеті мав основне значення, йому підпорядковувалося все (Кузовлева, 2013, с. 72-73).

Приголомшливий ефект «Весни» Стравінського і Ніжинського пояснюється традиційним для російського балету поєднанням композиторської та балетмейстерської думки: підхід до теми, її трактування, неординарні, але нерозривно пов’язані один з одним засоби виразності музики й танцю. Абсолютна асиметрія малюнків стала суттю побудови артистів на сцені. При цьому просторова й тек- 
стова композиції майстерно пов’язані одна з одною в єдине ціле, що проявляється в зустрічах, викликах, зіткненнях і конфліктах груп людей (Петренко, 2013, c. 43-44). Ніжинський звертається до жесту, і з нього народжується максимально виразний рух. Балетмейстер змушує «говорити» саме тіло танцівника. Заперечуючи загальноприйняте, протиставляючи себе відшліфованим канонам театрального танцю, котрі існували на початку XX ст., пластика Ніжинського висувала на перший план естетику експресіонізму, що прагне дати згусток почуттів у різких, грубих формах.

Після цього сезону компанія поїхала до Лондона, де 25 липня 1913 р. В. Ніжинський танцював востаннє в антрепризі С. Дягілєва. Того ж року Ніжинський одружується та залишає трупу Дягілєва. Після цього були невдалі спроби організувати власну компанію з допомогою сестри Броніслави (зокрема, у Лондоні), проте вони не мали значного успіху. Після майже півторарічної перерви Ніжинський повертається до антрепризи С. Дягілєва й розпочинає працю над створенням балету «Тіль Уленшпігель» на музику Р. Штрауса. Завершивши гастрольні виступи в Іспанії та Америці, В. Ніжинський, уражений тривалою психічною хворобою, оселяється з родиною у Швейцарії. По смерті Вацлава Ніжинського в 1950 р. за його могилою тривалий час доглядав Серж Лифар, який згодом купив на Монмартрському цвинтарі ділянку для перевезення туди тіла Ніжинського (Сидор, 2014, с. 187).

Подібною до життєвої і творчої долі брата була й доля сестри - Б. Ніжинської, яка окремими епізодами більш тісно пов’язана з діяльністю на теренах України та прагненням розвивати балетне мистецтво.

Броніслава разом зі своїм чоловіком, московським балетмейстером О. Кочетовським, протягом 1914-1917 рр. очолювала Київську балетну спільноту, принісши до Києва здобутки «Російських сезонів» С. Дягілєва та досягнення сучасного європейського балету.

Б. Ніжинська була віртуозною класичною танцівницею, виконуючи сольні партії в Маріїнському театрі. Але вона, як і її брат, шукала нових шляхів у мистецтві. Талант Б. Ніжинської, передусім як виконавиці характерних танців, а згодом і балетмейстера в трупі С. Дягілєва розкривався переважно на театральній сцені (Портнова, 2016, с. 20). Тогочасна ситуація в Україні не сприяла розвитку балетного мистецтва, що потребувало дисципліни й стабільності, і Б. Ніжинська це дуже добре розуміла. Тому одразу після революційних подій вона на деякий час переїхала до Москви. Проте в середині жовтня 1918 р. Ніжинська з Кочетовським повертається до Києва, а на початку 1919 р. відкривається її «Школа руху» театрально-балетна студія для виховання танцівників-акторів. На основі власного досвіду вона розробила нову методику навчання. Студійці вивчали класичну хореографію, вираження в рухах (міміку тіла), стиль у рухах, характерні танці, теорію музики, запис рухів. Відбираючи учнів для своєї студії, Ніжинська надавала перевагу тим, хто не мав попередньої хореографічної підготовки (Коваленко, 2012, с. 126). Майже до 1921 р. вона очолювала балетну студію при театрі, де свого часу навчався всесвітньо відомий артист балету й балетмейстер С. Лифар.

Б. Ніжинська вважала основою танцю рух, а не позу, вважаючи безглуздим, коли тіло танцівника рухається лише для того, щоб дивувати тією чи тією позою. Ведучи мову про рух, вона мала на увазі новий стиль танцю, який демонстрували М. Фокін, А. Павлова і, звичайно ж, В. Ніжинський. Мисткиня була знайома 3 різ- 
номанітною технікою і стилістикою балетного виконавства: $з$ академізмом М. Петіпа, котрий на той час досяг свого найвищого розвитку, значно вдосконаливши техніку; з імпресіонізмом М. Фокіна, з яким вона багато працювала, беручи участь у «Російських сезонах»; з новими модерністськими течіями у балеті. Відтак своїм учням Б. Ніжинська викладала і класичний танець, і характерний, модерний та багато інших його форм і стилів (Коваленко, 2012, с. 127).

Новий уряд доручив Б. Ніжинській очолити балетну трупу в новоствореній Українській опері, але в 1921 р. у зв'язку з тяжкою хворобою брата вона виїхала до Відня. ІЇ̈ подальше життя було пов'язане 3 «Російським балетом Дягилєва», де вона поставила свої кращі балети («Весіллячко» І. Стравінського, «Лані» Ф. Пуленка, «Блакитний експрес» Д. Мійо та ін.), - спектаклі, що стали класикою європейського мистецтва XX ст. Пізніше балетмейстер співпрацювала з багатьма трупами Лондона, Парижа, Берліна, Буенос-Айреса та США. Також Б. Ніжинській належить перша сценічна інтерпретація «Болеро» М. Равеля.

Серед новацій Б. Ніжинської у балеті можна виокремити активне використання спортивних рухів і фігур, уперше нею застосоване в постановці вистави Д. Мійо «Блакитний експрес». Багато хореографічних вирішень грунтувалися на різноманітних акробатичних трюках: сальто, перекиди, падіння, перевертання, стійки на голові, ходіння на руках та ін. Більш прості танцювальні рухи були засновані на музиці балету з невибагливими ритмами кадрилі й польки (Зінич, 2009, с. 82).

Б. Ніжинська привнесла власне бачення балету й ролі в ньому хореографіiі. Мисткиня виходила 3 концепції першості балетмейстера, а отже, наполегливо створювала свій власний балетмейстерський почерк. У перших виставах Б. Ніжинська в пошуках пластики відштовхувалася від досвіду свого брата Вацлава, який використовував «небалетні» прийоми, як-от у «Весні священній» (1913). Саме тому її вистави стали радше не балетами-видовищами у традиційному розумінні, а балетами-метафорами, адже фактично видовищний складник у них замінюється метафоричністю (Полисадова, 2017).

Так у не менш знаковій постановці вистави «Весіллячко», як і у «Весні священній» В. Ніжинського, головним носієм образного змісту є кордебалет. Він створює на сцені геометрично точні малюнки руху, активно переміщується по сцені й розпадається на групи, підкоряючись круговерті ритмів. Це породжує пластичні метафори, які доносять зміст основних моментів обрядодій. Незвичайне злиття класичного й характерного танцю створює сильний ефект (Кирпиченкова, 2015, с. 272).

Стосовно підтримки представників культурно-мистецької номенклатури, яка в часи життя Б. Ніжинської стрімко змінювалася, і висловлення власних поглядів варто зазначити, що мисткиня розуміла необхідність наявності професійної школи в будь-якій творчості. Вона чітко розмежовувала революційність у мистецтві із пропагандою революційних суспільних ідей або відображенням нової дійсності. На думку Б. Ніжинської, відпрацьована танцювальна техніка вже сама по собі була витвором мистецтва, а новаторством у театрі вона вважала зміну його форми. Щоб довести це на практиці, мисткиня залучила до роботи над власними постановками київських художників-авангардистів (Курінна, 2011, с. 75). Саме в Києві Б. Ніжинська активно співпрацювала у своїх постановках $з$ такими 
відомими художниками-авангардистами, як В. Меллер та О. Екстер, продемонструвавши плідні результати співпраці в костюмах та у сценографії низки вистав.

У творчому й науковому доробку Б. Ніжинської виокремлюється трактат «Школа і театр Руху». Уперше він був опублікований у віденському журналі «Der Schrifttanz» в 1930 р., а повторно - у сучасному збірнику «Мнемозина. Документы и факты из истории отечественного театра XX века» в 2014 р. (Нижинская, 2014).

Еміграційний період діяльності Б. Ніжинської, який розпочався в 1935 р., коли вона переїхала до США, позначений поглибленням творчих пошуків і новацій у балеті, що справило свій вплив на розвиток американського хореографічного мистецтва в цілому. Нововведення і розроблення Б. Ніжинської були сприйняті як питомо американські, що в подальшому активно розвивалося іншими митцями. Виїхавши до Америки, балетмейстер відкрила там свою школу. Після смерті Б. Ніжинської в лютому 1972 р. її дочка Ірина вирішила відновити балети в хореографії матері. 3 невеликою трупою Oakland Ballet (Балет Окленду) в Каліфорнії вона відновила в 1981 р. балет «Весіллячко», згодом - «Лані» і «Блакитний експрес»; усе це було здійснено завдяки художньому керівникові Р. Гуіді, що набув репутації реконструктора балетів початку XX ст. (Радина, 2016, с. 53).

Після смерті дочки Б. Ніжинської завдання з відтворення балетів лягли на плечі Ніни Юшкевич, танцівниці $з$ трупи «Російські балети Броніслави Ніжинської» і товаришки Ірини. У 1934 р. Н. Юшкевич виконувала роль травесті в «Болеро», а потім, емігрувавши до США у 1940 р., стала балериною Metropolitan Opera Ballet (Балет Meтрополітен-опера). У 1947 р. вона почала викладати в студії Б. Ніжинської в Голлівуді, а 31977 р. вела власні недержавні балетні класи в Нью-Йорку (Радина, 2016, с. 53).

Визначаючи внесок Б. Ніжинської в розвиток балетного мистецтва, варто зазначити, що саме вона збагатила академічну лексику своїх балетів оригінальною пластикою, позами з бодібілдингу, спортивними рухами й побутовим танцем. Це був індивідуальний іронічний погляд жінки-хореографа, яка створювала свій стиль у хореографічному мистецтві (Полисадова, 2017).

Особистий архів Б. Ніжинської зберігається в Бібліотеці Конгресу США у Вашингтоні.

Наукова новизна дослідження полягає в цілісній систематизації основних біографічних відомостей та особливостей творчого шляху В. та Б. Ніжинських, а також у висвітленні взаємозв'язку їхньої творчості зі світовим та українським балетним мистецтвом.

Висновки. Родинний тандем Вацлава та Броніслави Ніжинських належить до визначних явищ у розвитку хореографічного мистецтва України початку ХX ст.; він справив суттєвий вплив і на європейські та загальносвітові тенденції розвитку балетного мистецтва. Б. Ніжинська, творчий пошук якої здійснювався в середовищі новітніх авангардних ідей культури та мистецтва, $є$ автором педагогічних методів та принципів нової балетної школи руху, що склали важливе підгрунтя для формування професійної діяльності в тогочасному хореографічному мистецтві. Винятковий артистизм, пластичність та майстерність відзначають професійну творчу діяльність В. Ніжинського. У творчому доробку брата й сестри чимала кількість створених нових та балетних постановок, які слугували формуванню новітнього погляду на балетне мистецтво, модернізації ролі танцівника у виставі та особливостей розкриття образу. 


\section{СПИСОК БІБЛІОГРАФІЧНИХ ПОСИЛАНЬ}

Волхонович, Ю. (1997). Броніслава Ніжинська і Лесь Курбас. Український театр, 1, 10-13.

Гарафола, Л., \& Суриц, Е.Я. (2014). «Чернота делает росчерк в душе моей». В В.В. Иванов (Ред.), Мнемозина. Документы и факты из истории отечественного театра ХХ века (Вып. 6, с. 297-450). Москва: Индрик.

Зінич, О. (2009). Мова пластики в сучасному французькому балетному (пластичному) театрі: метаморфози форм руху. Студї мистецтвознавчі, 4(28), 80-89.

Кирпиченкова, О.В. (2015). Легендарная «Свадебка» Стравинского-Нижинской в интерпретациях И. Килиана и А. Прельжокажа. Вестник Академии Русского балета имени А. Я. Вагановой, 3(38), 271-276.

Коваленко, Є. (2012). Становлення українського балету перших десятиліть XX століття у контексті розвитку виконавського мистецтва. Мистецтвознавство України, 12, 123-132.

Кузовлева, Т.Е. (2013). «Весне священной» 100 лет. Театрон, 1(11), $72-76$.

Курінна, М. (2011). Про київський період творчості Броніслави Ніжинської. Студії мистецтвознавчі, 1, 72-78.

Нижинская, Б. (1999). Ранние воспоминания. Москва: Артист. Режиссер. Театр.

Петренко, Е.А. (2013). «Весна священная» И. Стравинского - В. Нижинского: к столетию спектакля. Искусствознание: теория, история, практика, 2(6), 42-46.

Полисадова, О.Н. (2016). Вацлав Нижинский: новые лексические смыслы хореографического искусства. Культура и цивилизация, 2, 75-83.

Полисадова, О.Н. (б.г.). Бронислава Нижинская и «Русский балет» Сергея Дягилева: авторский стиль и новаторские идеи. Взято из https://space.kpfu.ru/xmlui/bitstream/ handle/net/.../F_Iskobr2017_153_159.pdf?.

Портнова, Т.В. (2016). Художественная сфера деятельности артистов балета и хореографов на рубеже XIX - XX веков в искусствоведческом поле изучения. Москва: Научный консультант.

Радина, М.П. (2016). «Болеро»: РубинштейнРавельНижинская (К выпускным спектаклям Академии). Вестник Академии Русского балета имени А. Я. Вагановой, 2(43), 43-56.

Ратанова, М. (1999). Бронислава Нижинская: в тени легенды о брате. В Бронислава Нижинская. Ранние воспоминания (Ч. 1, с. 5-61). Москва: Артист. Режиссер. Театр.

Сидор, О. (2014). Портрет великого киянина на Венеційській бієнале 1912 року. Сучасне мистецтво, 10, 187-198.

Суриц, Е.Я. (2014). «...Всегда была преданным другом Вашим и Вашего дела». В В.В. Иванов (Ред.), Мнемозина. Документы и факты из истории отечественного театра ХХ века (Вып. 6, с. 451-480). Москва: Индрик.

Шабаліна, О. (2016). Розвиток українського хореографічного мистецтва на початку XX століття: джерела та тенденції. Вісник Львівської національної академії мистецтв, 28, 263-273.

\section{REFERENCES}

Garafola, L., \& Suritc, E.Ia. (2014). "Chernota delaet roscherk v dushe moei" ["Black makes a flourish in my soul"]. In V.V. Ivanov (Ed.), Mnemozina. Dokumenty i fakty iz istorii otechestvennogo teatra XX veka [Mnemosyne. Documents and facts from the history of the national theater of the twentieth century] (Issue 6, pp. 297-450). Moscow: Indrik [in Russian].

Kirpichenkova, O.V. (2015). Legendarnaia "Svadebka" Stravinskogo-Nizhinskoi v interpretatciiakh I. Kiliana i A. Prelzhokazha [Legendary "Weddings" Stravinsky-Nizhinsky in the 
interpretations of I. Kilian and A. Preljokazh]. Vestnik Akademii Russkogo baleta imeni A. Ia. Vaganovoi, 3(38), 271-276 [in Russian].

Kovalenko, Ye. (2012). Stanovlennia ukrainskoho baletu pershykh desiatylit XX stolittia u konteksti rozvytku vykonavskoho mystetstva [The formation of the Ukrainian ballet of the first decades of the twentieth century. in the context of the development of performing arts]. Mystetstvoznavstvo Ukrainy, 12, 123-132 [in Ukrainian].

Kurinna, M. (2011). Pro kyivskyi period tvorchosti Bronislavy Nizhynskoi [About the Kyiv period of creativity of Bronislava Nezhinskaya]. Studii mystetstvoznavchi, 1, 72-78 [in Ukrainian].

Kuzovleva, T.E. (2013). "Vesne sviashchennoi" 100 let ["Spring sacred" 100 years]. Teatron, 1(11), 72-76 [in Russian].

Nizhinskaia, B. (1999). Rannie vospominaniia [Early memories]. Moscow: Artist. Rezhisser. Teatr [in Russian].

Petrenko, E.A. (2013). "Vesna sviashchennaia" I. Stravinskogo - V. Nizhinskogo: k stoletiiu spektaklia ["Spring sacred" I. Stravinsky - V. Nizhinsky: to the centenary of the performance]. Iskusstvoznanie: teoriia, istoriia, praktika, 2(6), 42-46 [in Russian].

Polisadova, O.N. (2016). Vatclav Nizhinskii: novye leksicheskie smysly khoreograficheskogo iskusstva [Vaclav Nijinsky: new lexical meanings of choreographic art]. Kultura i tcivilizatciia, 2, 75-83 [in Russian].

Polisadova, O.N. (n.d.). Bronislava Nizhinskaia i "Russkii balet" Sergeia Diagileva: avtorskii stil i novatorskie idei [Bronislava Nizhinskaya and Sergei Dyagilev’s Russian Ballet: author's style and innovative ideas]. Retrieved from https://dspace.kpfu.ru/xmlui/bitstream/handle/net/.../F_Iskobr2017_153_159.pdf? [in Russian].

Portnova, T.V.(2016). Khudozhestvennaia sfera deiatelnosti artistov baleta $i$ khoreografov na rubezhe $X I X-X X$ vekov $v$ iskusstvovedcheskom pole izucheniia [The artistic field of activity of ballet dancers and choreographers at the turn of the XIX - XX centuries in the field of study of art criticism]. Moscow: Nauchnyi konsultant [in Russian].

Radina, M.P. (2016). "Bolero": RubinshteinRavelNizhinskaia (K vypusknym spektakliam Akademii) ["Bolero": Rubinstein Ravel Nizhinskaya (To the graduation performances of the Academy)]. Vestnik Akademii Russkogo baleta imeni A. Ia. Vaganovoi, 2(43), 43-56 [in Russian].

Ratanova, M. (1999). Bronislava Nizhinskaia: v teni legendy o brate [Bronislava Nizhinskaya: in the shadow of the legend of the brother]. In Bronislava Nizhinskaia. Rannie vospominaniia [Bronislava Nizhinskaya. Early memories] (Pt. 1, pp. 5-61). Moscow: Artist. Rezhisser. Teatr [in Russian].

Shabalina, O. (2016). Rozvytok ukrainskoho khoreohrafichnoho mystetstva na pochatku XX stolittia: dzherela ta tendentsii [The development of Ukrainian choreographic art at the beginning of the 20th century: sources and trends]. Visnyk Lvivskoi natsionalnoi akademii mystetstv, 28, 263-273 [in Ukrainian].

Suritc, E.Ia. (2014). "...Vsegda byla predannym drugom Vashim i Vashego dela" ["...Has always been a devoted friend of yours and your business"]. In V.V. Ivanov (Ed.), Mnemozina. Dokumenty $i$ fakty iz istorii otechestvennogo teatra XX veka [Mnemosyne. Documents and facts from the history of the national theater of the twentieth century] (Issue 6, pp. 451-480). Moscow: Indrik [in Russian].

Sydor, O. (2014). Portret velykoho kyianyna na Venetsiiskii biienale 1912 roku [Portrait of the great Kievan at the Venice Biennale of 1912]. Suchasne mystetstvo, 10, 187-198 [in Ukrainian].

Volkhonovych, Yu. (1997). Bronislava Nizhynska i Les Kurbas [Bronislav Nezhinsky and Les Kurbas]. Ukrainskyi teatr, 1, 10-13 [in Ukrainian].

Zinych, O. (2009). Mova plastyky v suchasnomu frantsuzkomu baletnomu (plastychnomu) teatri: metamorfozy form rukhu [Language of plastic in modern French ballet (plastic) theater: metamorphosis of forms of motion]. Studii mystetstvoznavchi, 4(28), 80-89 [in Ukrainian]. 